\title{
Elevated Enzyme Release from Lactococcal Starter Cultures on Exposure to the Lantibiotic Lacticin 481, Produced by Lactococcus lactis DPC5552
}

\author{
L. O’ Sullivan, ${ }^{\star} †$ S. M. Morgan, ${ }^{*} \ddagger$ R. P. Ross, ${ }^{*, 1}$ and C. Hill†’ \\ *Dairy Products Research Centre, \\ Teagasc, Moorepark, Fermoy, County Cork, Republic of Ireland \\ †Department of Microbiology and \\ $\ddagger$ National Food Biotechnology Centre, \\ University College Cork, Republic of Ireland
}

\begin{abstract}
A Lactococcus lactis subsp. lactis strain (DPC5552), which causes the lysis of other lactococcal cultures, was isolated during a screening of raw milk samples for bacteriocin producers. Purification of the bacteriocin produced revealed that production of the lantibiotic, lacticin 481, was associated with the bacteriolytic capability of the strain. However, unlike bacteriocin-induced lysis observed with bacteriocins such as lacticin 3147 and lactococcins A, B, and M (where the target strain is killed), the DPC5552 supernatant gave rise to a situation whereby the target strain continued to grow (albeit at a lower rate) with simultaneous release of the intracellular enzymes lactate dehydrogenase (LDH) and post-proline dipeptidyl aminopeptidase (Pep X). In parallel experiments, $32 \mathrm{AU} / \mathrm{ml}$ of the inhibitory activity from $L$. lactis DPC5552 resulted in a 10- and 6-foldhigher $\mathrm{LDH}$ release after $5 \mathrm{~h}$ than that with $32 \mathrm{AU} /$ $\mathrm{ml}$ of either lacticin 3147 or lactococcin A, B, and M. Laboratory-scale Cheddar cheese-making trials also demonstrated that lacticin 481-producing cultures induced the release of elevated levels of $\mathrm{LDH}$ from the starter L. lactis HP, without severely compromising its acid-producing capabilities. These results indicate that lacticin 481-producing strains may provide improved adjuncts for delivering lactococcal intracellular enzymes into the cheese matrix and, thus, improve cheese quality and flavor.
\end{abstract}

(Key words: cheese, lactate dehydrogenase, lacticin 481)

Abbreviation key: LDH = lactate dehydrogenase, $\mathbf{R S M}=$ reconstituted skim milk, Pep $\mathbf{X}=$ post proline dipeptidyl aminopeptidase $\mathbf{X}, \mathbf{O D}=$ optical density, $\mathbf{L A B}=$ lactic acid bacteria, TFA = trifluoroacetic acid .

Received November 2, 2001.

Accepted February 6, 2002.

Corresponding author: R. P. Ross; e-mail: pross@moorepark. teagasc.ie.

\section{INTRODUCTION}

Autolysis is a common feature among starter cultures and may be induced by heat- and freeze-shocking cells, increasing the $\mathrm{pH}$ and storage temperature of starter cultures (Bie and Sjöström, 1975a, 1975b), and by the induction of resident prophages in lysogenic starter strains (Feirtag and McKay, 1987a; O'Sullivan et al., 2000). Upon lysis, enzymes, including proteinases and peptidases, are released into the cheese matrix where they catalyze the breakdown of casein to low molecularweight peptides and free amino acids (Aston and Dulley, 1982; Aston and Creamer, 1986; Kamaly et al., 1989). These compounds are thought to be directly involved in flavor formation and also act as substrates for further flavor-forming reactions (Cliffe et al., 1993; Engels and Visser, 1994). Proteolysis is considered to be the rate-limiting step in the maturation of cheeses such as Cheddar. Consequently, increasing the rate of starter cell lysis (autolysis) and subsequent proteolysis may accelerate the ripening process (Crow et al., 1995a). In fact, autolysis is considered so important to cheese ripening that strains are being engineered to lyse upon environmental signals encountered during the cheese-making process (Feirtag and McKay, 1987b; Shearman et al., 1992). Numerous methods for increasing the rate of starter cell lysis have been investigated, including the direct addition of bacteriophage to cheesemilk vats (Crow et al., 1995b), the use of temperatureshocked starter cultures (Ardö and Petterson, 1988; Asensio et al., 1995), the treatment of cells with high hydrostatic pressures (Casal et al., 1996; Yokoyama et al., 1994), and the treatment of starter cells with lysozyme (Law et al., 1976).

Evidence exists to support the proposal that the extent of starter lysis has a direct effect on Cheddar cheese flavor and quality. The addition of a heat-treated mixed strain starter or heat-treated Lactobacillus helveticus in combination with an untreated mixed culture yielded increased lysis early in ripening and resulted in increased proteolysis compared with control cheese (Bie 
and Sjöström, 1975a, 1975b). A correlation was made between low bitterness in cheese and the high autolytic properties of the starter Lactococcus lactis subsp. cremoris AM2 (Chapot-Chartier et al., 1994). In a related study, the variability in autolytic properties among starter cultures was also explored by Wilkinson et al. (1994), who observed higher levels of low molecular mass peptides and free amino acids in cheese manufactured with the highly autolytic strain, L. lactis AM2. Importantly, these findings correlated with a nonbitter, more intense flavor in the cheese. Furthermore, bacteriocins may be used as cell-lysis-inducing agents, with a number of strains having been shown to have a lytic effect on starter cultures. Recently, it has been reported that the lytic effect of bacteriocins requires the presence of the major autolysin AcmA (Martínez-Cuesta et al., 2000).

A lactococcin A, B, and $\mathrm{M}$ producer (L. lactis DPC3286) was used as an adjunct culture in Cheddar manufacture to obtain lysis of a sensitive lactococcal starter, resulting in cheese with elevated intracellular enzyme levels and improved flavor development (Morgan et al., 1997). A broad-spectrum bacteriocin produced by L. lactis IFPL105 (Martínez-Cuesta et al., 2000) was exploited to induce lysis of two lactic acid bacteria commonly used in the manufacture of goats' milk cheese, and elevated levels of the intracellular enzyme post-proline dipeptidyl aminopeptidase (Pep X) was observed (Martínez-Cuesta et al., 1997). Further studies exploited this bacteriocin producer as an adjunct in cheese curd slurries whereby the lytic effect on the starter resulted in increased proteolysis (MartínezCuesta et al., 1998).

The first reported evidence of the bacteriolytic effect of bacteriocins on lactococci came from Kok et al. (1993), who observed that lactococcal cells treated with lactococcin A (Lcn A) released UV absorbing material. Most bacteriocins produced by lactic acid bacteria (LAB) exert their antibacterial effect by permeabilizing the cell membrane of the target strain and as a result the cells lose their viability (Abee, 1995; Bruno and Montville, 1993; Moll et al., 1988). The observation that bacteriocins cause loss of cell viability at least partially by inducing cell lysis of the target strain is indicated by a decrease in optical density (OD) of the culture (Morgan et al., 1995; Martínez-Cuesta et al., 1997).

The bacteriocin-producer L. lactis DPC5552 was isolated during a screening study of 500 raw milk isolates for potential bacteriocinogenic bacteria. This strain was found to have a medium spectrum of inhibition which is mainly restricted to lactococci but also to some lactobacilli, while Listeria innocua DPC1770, Bacillus coagulans 1761, and Enterococcus faecium are slightly sensitive to a concentrated ammonium sulfate preparation
Table 1. Source, phenotype, and culture conditions of the Lactococcus lactis bacterial strains used in this study.

\begin{tabular}{llll}
\hline Strain & $\begin{array}{l}\text { Growth } \\
\text { medium }\end{array}$ & Phenotype $^{1}$ & Source \\
\hline DPC5552 & LM17 & Lac+Prt+ & DPRC $^{2}$ \\
CNRZ 481 & LM17 & Lac+Prt+ & INRA $^{3}$ \\
DPC3147 & LM17 & Lac+Prt+ & DPRC \\
DPC3286 & GM17 & Lac-Prt- & DPRC \\
HP & LM17 & Lac+Prt+ & NZDRI \\
ML8 & LM17 & Lac+Prt+ & NZDRI \\
SK11G & LM17 & Lac+Prt+ & UCC \\
E8 & LM17 & Lac+Prt+ & NZDRI \\
MG1614 & GM17 & Lac-Prt- & Gasson (1983) \\
MG1363 & GM17 & Lac-Prt- & Gasson $(1983)$ \\
MG1614pCGB104 & GM17 & Lac-Prt- & Mills et al. (2001) \\
\hline
\end{tabular}

${ }^{1}$ Lac $=$ Lactose; Prt $=$ proteinase.

${ }^{2}$ Dairy Products Research Centre, Teagasc Moorepark, Fermoy, Co. Cork, Ireland.

${ }^{3}$ Institut National de la Recherche Agronomique, Jouy-en-Josas, France.

${ }^{4}$ New Zealand Dairy Research Institute, Palmerstown North, New Zealand.

${ }^{5}$ University College Cork, Ireland.

of the bacteriocin. This activity was partially heat stable over a $\mathrm{pH}$ range of 5 to 9 and was inactivated by proteinase $\mathrm{K}$, demonstrating that it was due to the production of a bacteriocin(s) (Cunniffe, 1998).

In this communication, we describe a physiological condition in lactococci that is characterized by a growing culture releasing the intracellular enzymes lactate dehydrogenase (LDH) and Pep X. This condition is induced upon exposure to the supernatant of $L$. lactis DPC5552, which on detailed investigation, was shown to contain the lantibiotic lacticin 481. Comparative studies with lacticin 3147 (L. lactis DPC3147) and lactococcins A, B, and M (L. lactis DPC3286) demonstrated that these bacteriocins resulted in an immediate cessation of growth of the target strain with concomitant lysis. Therefore, it would appear that the observation that lacticin 481 causes elevated enzyme release without the associated and expected decline in optical density of the target strain is a novel phenomenon for bacteriocin-induced lysis.

\section{MATERIALS AND METHODS}

\section{Bacterial Strains and Culture Conditions}

The bacterial strains used in this study are listed in Table 1. Lactococcal strains were maintained at $30^{\circ} \mathrm{C}$ on M17 (Terzaghi and Sandine, 1975), supplemented with $0.5 \% \mathrm{wt} / \mathrm{vol}$ lactose (LM17) or $0.5 \% \mathrm{wt} / \mathrm{vol}$ glucose (GM17) where necessary. Solid media were prepared by the addition of $1 \% \mathrm{wt} / \mathrm{vol}$ agar. Before laboratoryscale cheesemaking, strains L. lactis $\mathrm{HP}$ and L. lactis 481 were routinely transferred in $10 \% \mathrm{wt} / \mathrm{vol}$ reconsti- 
tuted skim milk (RSM) and incubated at $21^{\circ} \mathrm{C}$. L. lactis DPC5552 was routinely transferred in $10 \% \mathrm{wt} / \mathrm{vol}$ RSM and incubated at $30^{\circ} \mathrm{C}$, and L. lactis DPC3286 was transferred in $10 \% \mathrm{wt} / \mathrm{vol} \mathrm{RSM}$ supplemented with $0.5 \% \mathrm{wt} / \mathrm{vol}$ glucose and $0.5 \% \mathrm{wt} / \mathrm{vol}$ tryptone at $30^{\circ} \mathrm{C}$. All bacterial strains are stored at $-80^{\circ} \mathrm{C}$ in the DPC culture collection, Moorepark, Fermoy, Co. Cork, Ireland.

\section{Purification of the Antimicrobial Activity of $L$. lactis DPC5552}

The inhibitory activity produced by L. lactis DPC5552 was purified from a 4-L culture grown to stationary phase at $30^{\circ} \mathrm{C}$ in LM17 broth. Cells were removed by centrifugation at $7000 \times g$ for $60 \mathrm{~min}$ and the supernatant treated with $55 \% \mathrm{wt} / \mathrm{vol}$ ammonium sulfate overnight with constant stirring at $4^{\circ} \mathrm{C}$. This preparation was allowed to settle before centrifugation of the supernatant at $7000 \times g$ for $60 \mathrm{~min}$. The resulting pellet and pellicle (layer at top of supernatant) were combined and resuspended in $100 \mathrm{ml}$ of $20 \mathrm{~m} M$ sodium phosphate buffer $\mathrm{pH}$ 7. This fraction was applied to a column (3 $\times 23 \mathrm{~cm}$ ) containing $50 \mathrm{~g}$ of XAD 16 beads (Sigma Chemicals Co., Poole, Dorset, U.K.). The column was washed with $1 \mathrm{~L}$ sterile distilled deionized water followed by 2 $\mathrm{L}$ of $30 \%$ ethanol and the inhibitory activity eluted with $70 \%$ isopropanol. The isopropanol was removed by evaporation at $30^{\circ} \mathrm{C}$ using a rotavaporator (Buchi, AGB Scientific, Ltd., Dublin, Ireland). One hundred milliliters of this sample was applied to a SP-Sephadex cation exchange column $(3 \times 23 \mathrm{~cm})$, which had been previously equilibrated with citrate-phosphate buffer, $\mathrm{pH} 4.2$ (buffer A). After sample application, the column was washed four times with buffer A. Inhibitory activity was eluted in 4-ml fractions with $1 M \mathrm{NaCl}$ in buffer A at a flow rate of $2 \mathrm{ml} / \mathrm{min}$. The most active fractions from the cation exchange column were pooled and applied to a HPLC C18 reverse-phase column (Pharmacia, LKB Biotechnology, Uppsala, Sweden) equilibrated with $0.1 \% \mathrm{vol} / \mathrm{vol}$ trifluoroacetic acid (TFA) in sterile distilled water. The inhibitory activity was eluted with $\sim 48 \% \mathrm{vol} / \mathrm{vol}$ isopropanol containing $0.1 \% \mathrm{vol} / \mathrm{vol}$ TFA at a flow rate of $1 \mathrm{ml} / \mathrm{min}$. Active fractions were pooled and concentrated by evaporation with $\mathrm{N}_{2}$ gas. This HPLC chromatographic step was repeated to obtain purified bacteriocin for analysis. All purification steps were performed at room temperature.

\section{N-Terminal Amino Acid Sequencing and Mass Spectrometry Analysis}

The purified bacteriocin was hydrolyzed, and the partial amino acid sequence was determined by automated
Edman degradation with a model 420A sequencer equipped with on-line PTC analysis (Applied Biosystems, Foster City, CA). Mass spectrometry was performed with a Perseptive Biosystems Voyager-DE STR Biospectrometry Workstation. Both procedures were carried out by B. Dunbar, Department of Molecular and Cell Biology, University of Aberdeen, Aberdeen, Scotland.

\section{Isolation of DNA and Polymerase Chain Reaction and DNA Sequence Analysis}

Genomic DNA was extracted from lactococci according to the method outlined by Hoffman and Winston (1987).

Oligonucleotide primers for PCR were synthesized by MWG Biotech, Milton Keynes, U.K. The primers were designed to amplify a 1142-bp sequence, which encompasses the lacticin 481 structural gene, lctA (Piard et al., 1993). The reaction mixture of $50 \mu \mathrm{l}$ consisted of: $1 \mu \mathrm{l}$ of template DNA (diluted 1:10 in $\mathrm{sdH}_{2} 0$ ), 1 $\mu M$ each of primer 1 ( $5^{\prime}$ GGAGCATACCCTGTTCC $\left.{ }^{\prime}\right)$ and primer 2 (5'TATTTAGTGCTTTTTCCCTCTTTA'), 0.4 $\mathrm{m} M$ of each dNTP, 1 X reaction buffer, $3 \mathrm{mM} \mathrm{MgCl}_{2}$, and $0.03 \mathrm{U}$ of Taq DNA polymerase (Boehringer Mannheim). Amplification reactions were performed with a 1-min hot start at $93^{\circ} \mathrm{C}$ followed by 30 cycles of denaturation at $93^{\circ} \mathrm{C}$ for $1 \mathrm{~min}$, primer annealing at $62^{\circ} \mathrm{C}$ for 1 min, and primer extension at $72^{\circ} \mathrm{C}$ for $1 \mathrm{~min}$. Reactions were performed in a Touchdown thermal cycler (Hybaid Medical Supply Co., Dublin, Ireland). Five microliters of the resulting amplified DNA was electrophoresed in a $1.5 \% \mathrm{wt} / \mathrm{vol}$ agarose gel and analyzed after ethidium bromide staining.

Template DNA for sequencing was column purified from an original volume of $40 \mu \mathrm{l}$ of PCR product using a QIAquick PCR purification kit (QIAGEN) as per the manufacturer's instructions. Sequencing was performed using a LI-COR 4200 system (MWG Biotech, Milton Keynes, U.K.) using primers designed to encompass the DNA sequence of the lacticin 481 structural gene.

\section{Bacteriocin Activity Assay}

Bacteriocin activity was quantified by means of a well-diffusion assay as described by Parente and Hill (1992). This involved punching wells into an agar plate seeded with an overnight test culture, L. lactis HP (100 $\mu \mathrm{l}$ of culture $/ 20 \mathrm{ml}$ of agar). Twofold serial dilutions of cell-free supernatant were then added to the wells (50 $\mu \mathrm{l})$ and the plates incubated at $30^{\circ} \mathrm{C}$ overnight. Bacteriocin activity was defined as the reciprocal of the highest dilution demonstrating complete inhibition of the 
indicator lawn and was expressed as arbitrary units per milliliter (AU/ml).

\section{Investigation of the Lytic} Ability of L. lactis DPC5552

An overnight culture of L. lactis MG1614 was inoculated into GM17 broth at an inoculation level of $2 \%$ (vol/ vol), and culture growth was monitored until reaching $\mathrm{OD}_{600 \mathrm{~nm}}$ of $\sim 0.3$. The culture was dispensed aseptically into $25-\mathrm{ml}$ volumes. Filter-sterilized $(0.45-\mu \mathrm{m}$ HVLP filters, Millipore) bacteriocin supernatant (or purified bacteriocin) was added (at the required concentrations), and the volumes were adjusted to a final volume of 50 $\mathrm{ml}$ with GM17 broth. The cultures were reincubated at $30^{\circ} \mathrm{C}$, and $\mathrm{OD}_{600 \mathrm{~nm}}$ readings were recorded at hourly intervals. Lysis of the culture was determined by measuring levels of the intracellular enzymes LDH and Pep $\mathrm{X}$ in the culture supernatant. L. lactis MG1614 counts were enumerated on GM17 agar. For comparative purposes, this experiment was also performed with the bacteriocins lacticin 3147 and lactococcins A, B, and M.

\section{Measurement of Intracellular Enzyme Release}

LDH was determined by the procedure outlined by Wittenberger and Angelo (1970), using sodium pyruvate as a substrate. The oxidation of $\mathrm{NADH}$ was followed by monitoring the decrease in OD at $340 \mathrm{~nm}$ of the assay mixture in a Milton Roy Spectronic R Genesis spectrophotometer. Activity was expressed as $\mathrm{U} / \mathrm{ml}$ of supernatant, where $1 \mathrm{U}$ is the amount of enzyme that catalyzes the oxidation of $1 \mu M$ of $\mathrm{NADH} / \mathrm{min}$ per milliliter of supernatant.

Pep X was quantified by a modified version of the method of Booth et al. (1990) as follows: $50 \mu$ l of culture supernatant was incubated with a $900-\mu \mathrm{l} 50 \mathrm{mM}$ potassium phosphate buffer, $\mathrm{pH} 7.5$ at $37^{\circ} \mathrm{C}$ for $5 \mathrm{~min}$. Fifty microliters of the substrate $(10 \mathrm{~m} M$ Gly-Pro-AMC in methanol) was then added to the sample-in-buffer and incubated for an additional $30 \mathrm{~min}$ at $37^{\circ} \mathrm{C}$. The reaction was terminated by the addition of $1 \mathrm{ml}$ of 1.5 $M$ acetic acid. The degree of hydrolysis was determined by measurement of the fluorescence of the sample due to the release of 7-amino-4-methyl coumarine at excitation and emission wavelengths of 370 and $440 \mathrm{~nm}$, respectively (SFM 25 Spectralfluorimeter, Kontron Instruments, Zurich, Switzerland). Activity is given in units, where $1 \mathrm{U}$ is the amount of enzyme required to release $1 \mathrm{nmol}$ of $\mathrm{AMC}$ at $37^{\circ} \mathrm{C}$ per minute per milliliter of sample.

\section{Confocal Scanning Laser Microscopy}

In situ confocal scanning laser microscopy observations and viability staining of bacterial cells were per- formed on an L. lactis ML8 culture according to the method outlined by Auty et al. (2001). The culture was treated with DPC3286 bacteriocin and DPC5552 bacteriocin, and untreated as a control and incubated for 4 $\mathrm{h}$ at $30^{\circ} \mathrm{C}$. One hundred microliters of culture was mixed with an equal volume of LIVE/DEAD Baclight stain (Molecular Probes, Inc., Eugene, OR), and $5 \mu \mathrm{l}$ of this mix was viewed to obtain CSLM images after $20 \mathrm{~min}$ of incubation in the dark at room temperature.

\section{Laboratory-Scale Cheddar Cheese Manufacture}

Cultures were inoculated into 500-ml volumes of milk and taken through the Cheddar cheese temperature profile (Heap and Lawrence, 1981) with a cooking temperature of $38^{\circ} \mathrm{C}$. Chymax rennet (Hansens, Little Island, Cork, Ireland) was added according to manufacturer's instructions, and the curd cut $\sim 30 \mathrm{~min}$ after rennet addition. The whey was drained at $\mathrm{pH} 6.2$, and the curd milled and salted (2.5\% wt/wt) at pH 5.2. Following cheese manufacture, samples of curd were centrifuged at 20,000 g for $10 \mathrm{~min}$ (Eppendorf 5417C), and the resulting aqueous phase was assayed for LDH activity.

\section{RESULTS}

The bacteriocin-producing strain L. lactis DPC5552, isolated from raw milk, has a medium spectrum of inhibition. Preliminary experiments with this culture suggested that it may provide an improved adjunct to elicit the lysis of starter strains since it caused substantial enzyme release when compared with other bacteriocinogenic strains. For this reason, the bacteriocin it produces was initially characterized in detail before further investigations into its lytic capabilities.

\section{The Bacteriocin-Producing Strain DPC5552 Produces the Lantibiotic Lacticin 481}

The bacteriocin produced by L. lactis DPC5552 was purified by a combination of ammonium sulphate precipitation and application to $\mathrm{XAD}-16$ hydrophobic beads. Chromatography on the SP-Sepharose column followed, finally, by repeated reverse-phase chromatography to obtain a pure bacteriocin preparation suitable for sequencing. The molecular weight of the bacteriocin as determined by mass spectrometry analysis was 2900.93 (Figure 1a), almost identical to that determined for lacticin 481 (2901 Da), a broad spectrum lantibiotic produced by $L$. lactis CNRZ 481 (Piard et al., 1992) and L. lactis ADRIA 85LO30 (Rince et al., 1994). Other peaks evident in the mass spectrum are most probably different forms of the bacteriocin arising from oxidation or hydrogenation reactions. 


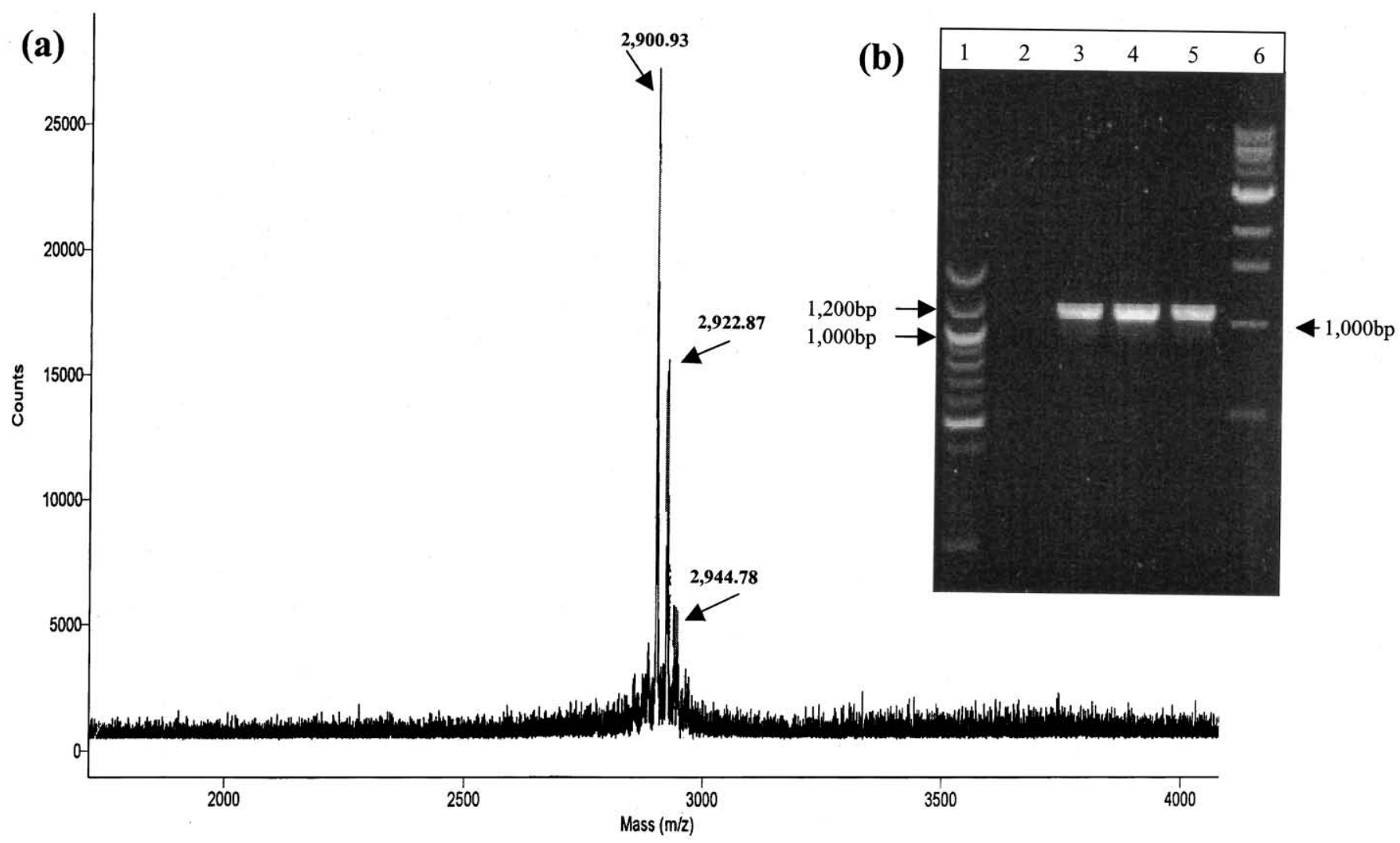

Figure 1. (a) Mass spectrum of the peptide purified from Lactococcus lactis DPC5552. A peak representing a protein of 2900.93 Da can be identified. The molecular weight of lacticin 481 is 2901 and (b) Identification of the lacticin 481 structural gene, lct A, and a portion of the modification gene lct $M$, by PCR using primers designed to amplify a 1142-bp region of the operon. A linear 100-bp DNA ladder (lane 1) and a 1-kb DNA ladder (lane 6) were used as size markers. Lanes 2: negative control (L. lactis MG1614 genomic DNA as template); 3: positive control (L. lactis MG1614pCBG104 genomic DNA as template); 4: positive control (L. lactis CNRZ 481 genomic DNA as template); 5: L. lactis DPC5552 genomic DNA as template. A band corresponding to a fragment of $1142 \mathrm{bp}$ is evident in lanes 3, 4, and 5, indicating that $L$. lactis DPC5552 contains the gene for lacticin 481 biosynthesis.

$\mathrm{N}$-Terminal sequencing revealed that the first 20 amino acid residues of the mature peptide produced by DPC5552 were identical to those of lacticin 481, with the exception of unidentifiable residues at positions 9 , 11,14 , and 18 (Table 2). Because the mature peptide largely lacks threonine, serine, and cysteine residues, which are usually well represented amino acids in proteins, it is proposed that due to posttranslational modification of the prepeptide, the undetermined moieties are modified forms of these residues. In this respect, based on the structure of lacticin 481, residues at positions 9, 11, 14, and 18 are involved in ring formation.

Genetic evidence that $L$. lactis DPC5552 produces lacticin 481 was obtained via PCR. Primers based on the DNA sequence of the lacticin 481 structural gene lct $A$ were used to amplify the gene. An identically sized fragment ( 1142 bp) was amplified from DPC5552, $L$. lactis MG1614 pCBG104 (L. lactis MG1614 containing the plasmid which encodes for 481 production) and CNRZ 481 genomic DNA using these primers (Figure 1b). Sequencing of the product revealed $100 \%$ identity over 655 bases to the published sequence for lacticin 481 (Rince et al., 1994). This sequence includes the entire structural gene lctA and 245 bases of the gene lct $M$ which encodes the modification protein (data not shown).

\section{Lacticin 481 Induces Elevated Enzyme Release in Lactococci}

To investigate whether lacticin 481 has a bacteriolytic effect on other lactococcal strains, a purified preparation of lacticin 481 was added in increasing concentrations to an exponentially growing $L$. lactis MG1614 culture. An 15 -fold increase in the level of the intracellular enzyme LDH was observed upon addition of $8 \mathrm{AU} / \mathrm{ml}$ of the purified bacteriocin while the culture maintained an active but reduced rate of growth (Figure 2 ). To investigate this phenomenon further, supernatants from lacticin 481-producing strains were tested 
Table 2. A comparison of the first 20 amino acids of the lacticin 481 sequence from Lactococcus lactis CNRZ 481, with that obtained for the peptide purified from $L$. lactis DPC5552.

\begin{tabular}{lll}
\hline & Peptide from & \\
Residue no. & L. lactis DPC5552 & Lacticin $481^{1}$ \\
\hline 1 & Lys & Lys \\
2 & Gly & Gly \\
3 & Gly & Gly \\
4 & Ser & Ser \\
5 & Gly & Gly \\
6 & Val & Val \\
7 & Ile & Ile \\
8 & His & His \\
9 & X (modified Thr) & Abu \\
10 & Ile & Ile \\
11 & X (modified Ser) & Ala* \\
12 & His & His \\
13 & Glu & Glu \\
14 & ND & Ala* \\
15 & Asn & Asn \\
16 & Met & Met \\
17 & Asn & Asn \\
18 & X (modified Ser) & Ala* \\
19 & Trp & Trp \\
20 & Glu & Glu \\
\hline
\end{tabular}

${ }^{1}$ Sequence obtained from Piard et al. (1993).

${ }^{2} \mathrm{Ala}$ and $\mathrm{Abu}$ represent the alanyl- and $\beta$-methylalanyl-moieties of lanthionines.

${ }^{3} \mathrm{ND}$, resonance could not be identified.

for their bacteriolytic effect against a number of lactococcal starter cultures.

\section{Lacticin 481-Producing Culture Supernatants Cause Elevated Enzyme Release in Lactococci}

Culture supernatants of DPC5552 cause the release of the intracellular enzymes LDH and Pep X from an
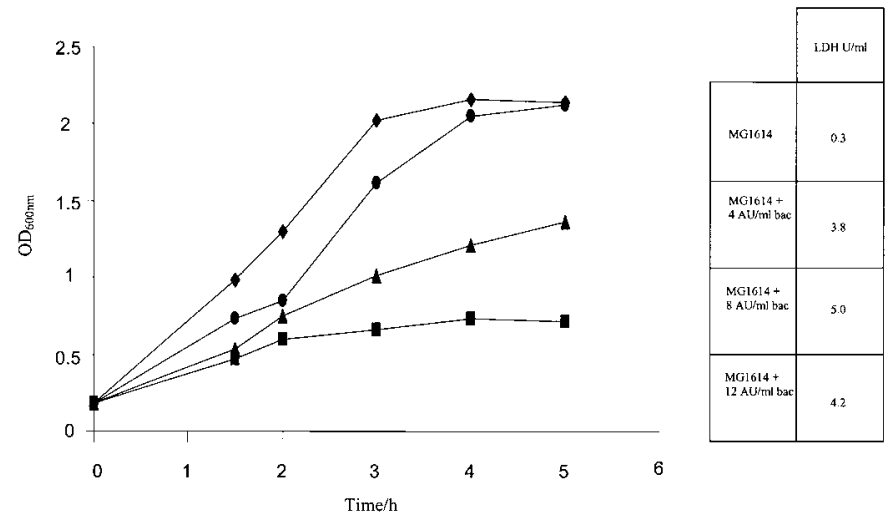

Figure 2. Growth curve for MG1614 treated with increasing concentrations of purified lacticin 481 and corresponding levels of lactate dehydrogenase (LDH) in the culture supernatant after $5 \mathrm{~h}$. MG1614: $(\diamond) ;$ MG1614 + 4 AU/ml purified bacteriocin: $(\bullet)$; MG1614 + 8 AU/ ml purified bacteriocin: $(\bullet)$; MG1614 +12 AU/ml purified bacteriocin: (ם).

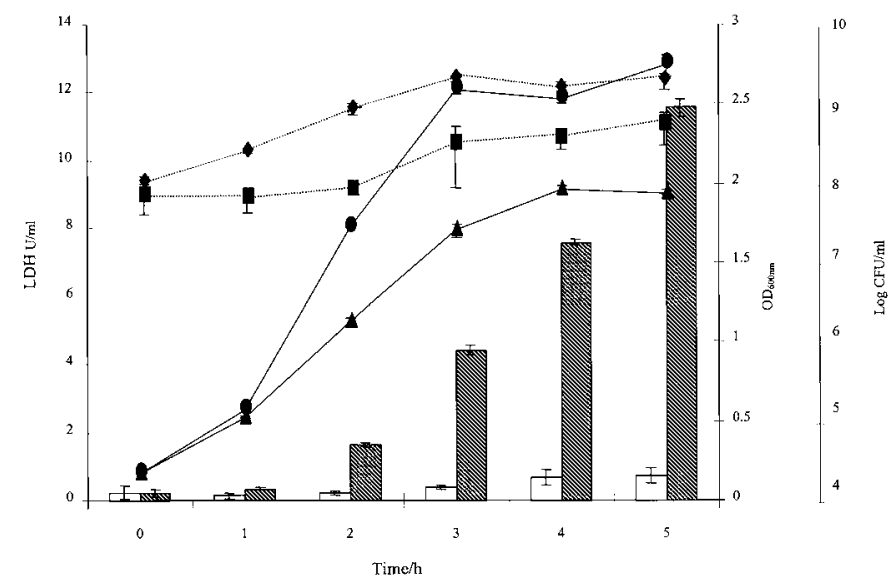

Figure 3. Growth curve for untreated MG1614 (O) and treated with $8 \mathrm{AU} / \mathrm{ml}$ Lactococcus lactis DPC5552 supernatant ( ) and corresponding levels of lactate dehydrogenase (LDH) detected in the supernatant at each time point during the 5-h incubation, from untreated MG1614 (white boxes) and bac-treated MG1614 (black/white boxes). Dashed line with diamond represents the growth of untreated MG1614 in Log cfu/ml, and dashed line with black square represents the growth of bac-treated MG1614 in Log cfu/ml. Error bars represent the standard deviation of triplicate readings.

exponentially growing $L$. lactis MG1614, without an associated decline in OD, which would normally be expected for such elevated enzyme levels. As evidenced in Figure 3, under normal conditions (in the absence of DPC5552 supernatant), a L. lactis MG1614 culture grows to stationary phase over a 5 -h incubation period, during which time it releases a basal level of intracellular LDH. Growth of the culture is also demonstrated by bacterial counts illustrated as Log $\mathrm{cfu} / \mathrm{ml}$. However, in the presence of $8 \mathrm{AU} / \mathrm{ml}$ DPC5552 supernatant, the L. lactis MG1614 culture continues to grow, albeit at a growth rate almost half that of the control ( $\mathrm{K}$ values of $\sim 0.593$ and $\sim 1.081 \mathrm{OD}_{600 \mathrm{~nm}} / \mathrm{h}$, respectively), and a gradual release of lactate dehydrogenase is observed in that time period. Following the 5-h incubation, there is an $\sim 5$-fold difference in colony-forming units (cfu) between the control and bacteriocin-treated $L$. lactis MG1614 culture and an 16-fold increase in the level of $\mathrm{LDH}$ released. In a further experiment, various concentrations of culture supernatant (from an overnight culture of DPC5552) were added to exponentially growing L. lactis MG1614 cells. For comparative purposes, parallel experiments were performed with culture supernatants from L. lactis DPC3147 (lacticin 3147 producer) and L. lactis DPC3286 (lactococcin A, B, and $\mathrm{M}$ producer). As expected, supernatants from all three bacteriocin-producing strains inhibited $L$. lactis MG1614 (Figure 4). The extent of inhibition was dependent on bacteriocin concentration. Interestingly, however, was the observation that the L. lactis MG1614 
(a)

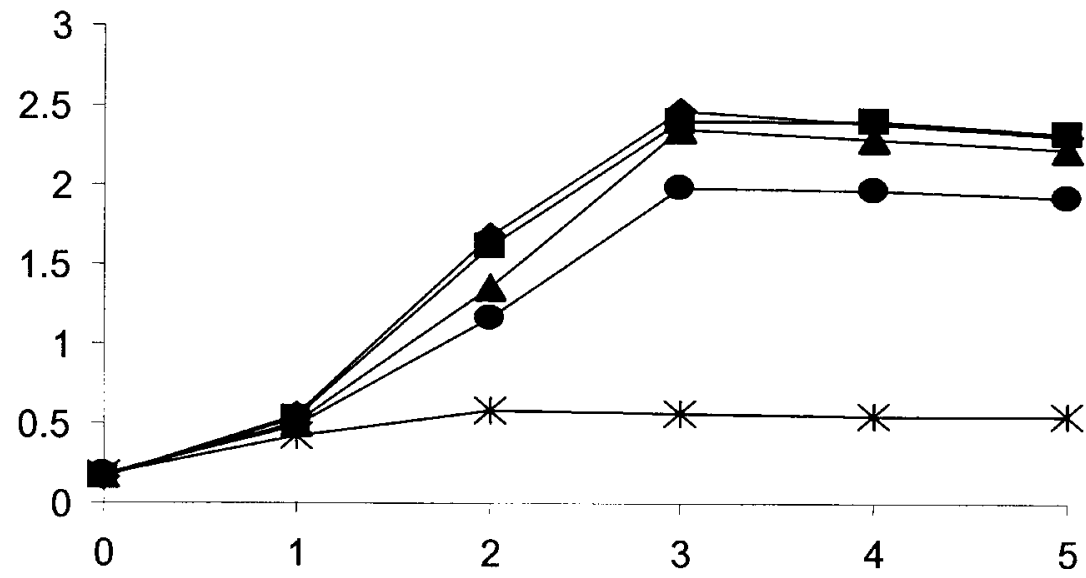

(b)

(c)

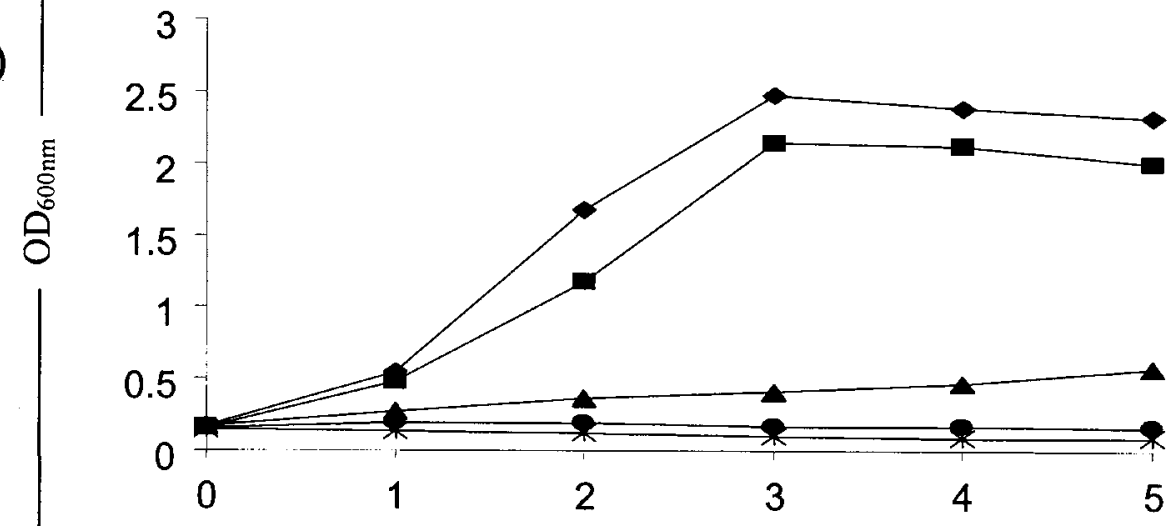

\begin{tabular}{|c|c|c|}
\hline $\begin{array}{l}\text { MG1614+ } \\
\text { lacticin } 481\end{array}$ & $\begin{array}{l}\mathrm{LDH} \\
\mathrm{U} / \mathrm{ml}\end{array}$ & $\begin{array}{l}\text { Pep X } \\
\mathrm{nmol} / \mathrm{min} /\end{array}$ \\
\hline()$^{M G 1614}$ & 0.76 & 0.22 \\
\hline $\begin{array}{l}\text { MG1614+ } \\
\text { (D) } 0.5 \mathrm{AU} / \mathrm{ml} \mathrm{bac}\end{array}$ & 0.76 & 0.26 \\
\hline $\begin{array}{c}\text { MGl614 + } \\
\text { (A) } 2 \mathrm{AU} / \mathrm{ml} \text { bac }\end{array}$ & 1.77 & 0.60 \\
\hline $\begin{array}{cc}\text { MG1614 + } \\
8 \mathrm{AU} / \mathrm{ml} \text { bac }\end{array}$ & 6.98 & 3.20 \\
\hline (メ) $\begin{array}{l}\text { MGl614 } \\
32 \mathrm{AU} / \mathrm{ml} \text { bac }\end{array}$ & 12.44 & 4.94 \\
\hline
\end{tabular}

\begin{tabular}{|c|c|c|}
\hline $\begin{array}{l}\text { MG1614 + } \\
\text { lactococcins }\end{array}$ & $\begin{array}{l}\mathrm{LDH} \\
\mathrm{U} / \mathrm{ml}\end{array}$ & $\begin{array}{l}\text { Pep X } \\
\text { nmol/min }\end{array}$ \\
\hline (๑) ${ }^{\text {MG1614 }}$ & 0.76 & 0.22 \\
\hline $\begin{array}{c}\mathrm{MG1614+} \\
\text { (D) } 0.5 \mathrm{AU} / \mathrm{ml} \mathrm{bac}\end{array}$ & 0.57 & 0.19 \\
\hline $\begin{array}{r}\text { MG1614 + } \\
\text { (A) } 2 \mathrm{AU} / \mathrm{ml} \text { bac }\end{array}$ & 0.47 & 0.09 \\
\hline $\begin{array}{l}\text { MGl614 + } \\
8 \mathrm{AU} / \mathrm{ml} \text { bac }\end{array}$ & 0.67 & 0.19 \\
\hline $\begin{array}{c}\mathrm{MG1614+} \\
(\chi) 32 \mathrm{AU} / \mathrm{ml} \text { bac }\end{array}$ & 2.10 & 1.82 \\
\hline
\end{tabular}

\begin{tabular}{|c|c|c|}
\hline $\begin{array}{l}\text { MG1614 + } \\
\text { lacticin } 3147\end{array}$ & $\begin{array}{l}\mathrm{LDH} \\
\mathrm{U} / \mathrm{m} 1\end{array}$ & $\begin{array}{l}\text { Pep X } \\
\text { nmol/min }\end{array}$ \\
\hline$\Leftrightarrow)^{\text {MG1614 }}$ & 0.76 & 0.22 \\
\hline $\begin{array}{c}\mathrm{MGl} 614+ \\
\text { (D) } 0.5 \mathrm{AU} / \mathrm{ml} \mathrm{bac}\end{array}$ & 0.81 & 0.29 \\
\hline $\begin{array}{r}\mathrm{MG} 1614+ \\
\text { (A) } 2 \mathrm{AU} / \mathrm{ml} \text { bac }\end{array}$ & 0.62 & 0.21 \\
\hline $\begin{array}{r}\text { MG1614 + } \\
8 \mathrm{AU} / \mathrm{ml} \text { bac }\end{array}$ & 0.38 & 0.08 \\
\hline (メ) $\begin{array}{c}\text { MG1614 } \\
32 \mathrm{AU} / \mathrm{ml} \text { bac }\end{array}$ & 1.19 & 0.28 \\
\hline
\end{tabular}

0

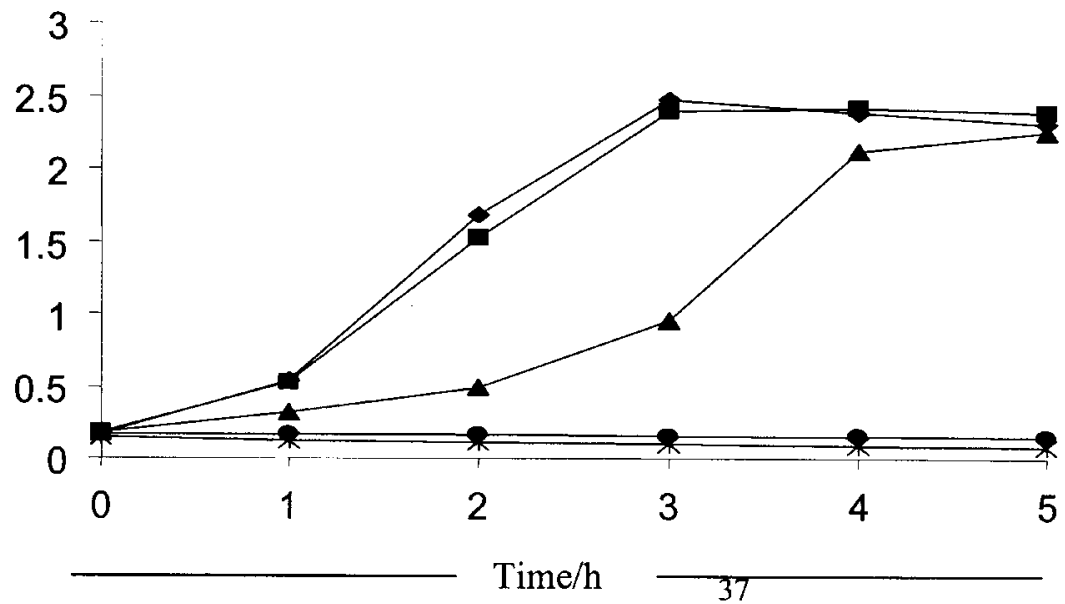

5

Figure 4. Growth curve for MG1614 treated with increasing concentrations of (a) Lactococcus lactis DPC5552 bacteriocin (lacticin 481 ), (b) L. lactis 3286 bacteriocin (lactococcin A, B and M) and (c) L. lactis 3147 bacteriocin (lacticin 3147) and corresponding levels of lactate dehydrogenase (LDH) and post-proline dipeptidyl aminopeptidase X (Pep X) detected in the culture supernatant after 5 hours incubation at $30^{\circ} \mathrm{C}$. MG1614: $(\bullet)$; MG1614 + 0.5 AU/ml bacteriocin: $(\mathbf{\square}) ;$ MG1614 + 2 AU/ml bacteriocin: $(\bullet)$; MG1614 +8 AU/ml bacteriocin: $(\bullet)$; MG1614 + 32 AU/ml bacteriocin: $(\times)$.

culture treated with DPC5552 supernatant (Figure 4a) differed from that treated with the other bacteriocincontaining supernatants. The L. lactis MG1614 continued to grow, even when exposed to $8 \mathrm{AU} / \mathrm{ml}$ DPC5552 supernatant (a concentration that proved bactericidal with lacticin 3147 and lactococcins A, B, and M). At this concentration, levels of $\mathrm{LDH}$ from $L$. lactis MG1614 were 18.4 and 10.4 times higher than in the presence 


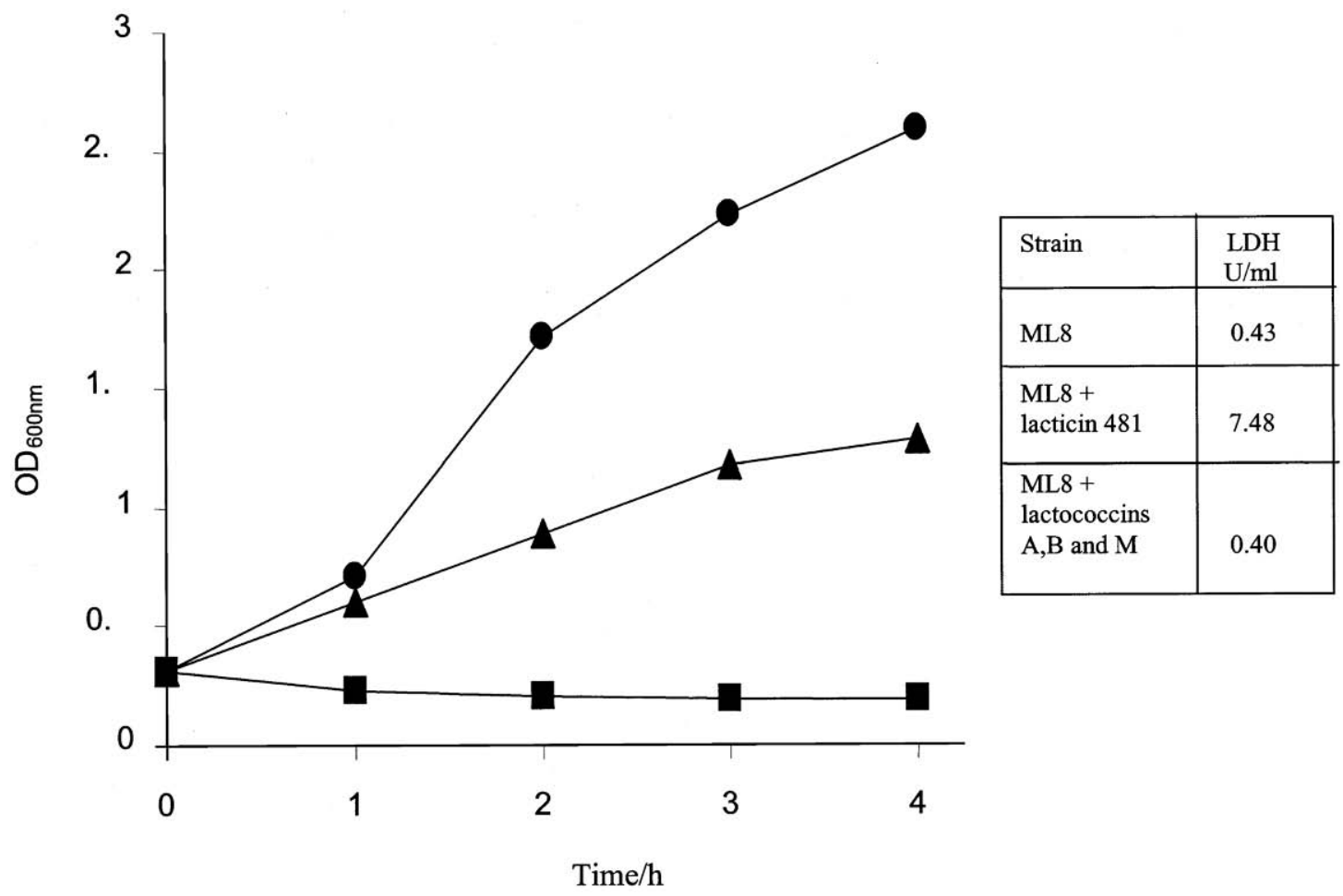

Figure 5. Growth curve of untreated ML8 (๑) and treated with 512AU/ml L. lactis DPC5552 supernatant (•) and 512 AU/ml L. lactis DPC3286 supernatant (ם) during a 4-h incubation at $30^{\circ} \mathrm{C}$, respectively.

of lacticin 3147 and the lactococcins, respectively, at 5 h. In addition, levels of Pep X were 42.6 and 16.7 times higher than from L. lactis MG1614 treated with lacticin 3147 or lactococcin containing supernatant, respectively, at $5 \mathrm{~h}$. In contrast, only the highest concentration of $32 \mathrm{AU}$ of lacticin 3147 or lactococcins per milliliter of supernatant resulted in significant intracellular enzyme release.

However, considerable interstrain variation exists with different lactococcal starters in regard to their sensitivities to lacticin 481. For example, growth of $L$. lactis MG1614 is slow in the presence of a bacteriocin concentration of DPC5552 supernatant of $32 \mathrm{AU} / \mathrm{ml}$, whereas in the presence of $512 \mathrm{AU} / \mathrm{ml}$ of bacteriocin, ML8 retains active growth (Figure 5). Investigations into the ability of DPC5552 supernatant to induce lysis of other L. lactis strains were performed. Such strains included ML8, MG1363, HP, SK11G, and E8. As observed with L. lactis MG1614, elevated enzyme release was observed from these strains without severely compromising cell viability (data not shown).

Increasing concentrations of L. lactis CNRZ 481 supernatant were also added to an exponentially growing L. lactis MG1614 culture. As observed with DPC5552, this strain retained active growth in the presence of the bacteriocin and simultaneously released significantly more $\mathrm{LDH}$, at all bacteriocin concentrations used, than from the untreated control; e.g., addition of $\sim 5 \mathrm{AU} / \mathrm{ml}$ lacticin 481-containing supernatant generated a sixfold increase in LDH over the control.

\section{Baclight LIVE/DEAD Staining to Assess Starter Viability}

Baclight LIVE/DEAD staining was used as a tool to assess the viability of L. lactis ML8 following treatment with bacteriocins produced by DPC3286 (lactococcins A, B, and M) and DPC5552 (lacticin 481). The assessment of viability was designed specifically to differentiate between live cells (stained green) and dead bacterial cells (stained red) based on membrane permeability. In the case of the untreated ML8 control, $5 \%$ of the cells stained red after $4 \mathrm{~h}$, and $95 \%$ of cells stained green (data not shown). The corresponding level of LDH released from the untreated ML8 cells was $0.43 \mathrm{U} / \mathrm{ml}$ (Figure 5). Where cells are treated with $512 \mathrm{AU} / \mathrm{ml}$ DPC5552 supernatant, $45 \%$ stained green, and 55\% stained red. The corresponding level of LDH released was $7.48 \mathrm{U} / \mathrm{ml}$. In contrast, $100 \%$ of ML8 cells stained red after $4 \mathrm{~h}$ of incubation in the presence of $512 \mathrm{AU} / \mathrm{ml}$ of the lactococcins produced by DPC3286. Interestingly, the level of $\mathrm{LDH}$ released from these nonviable cells is 


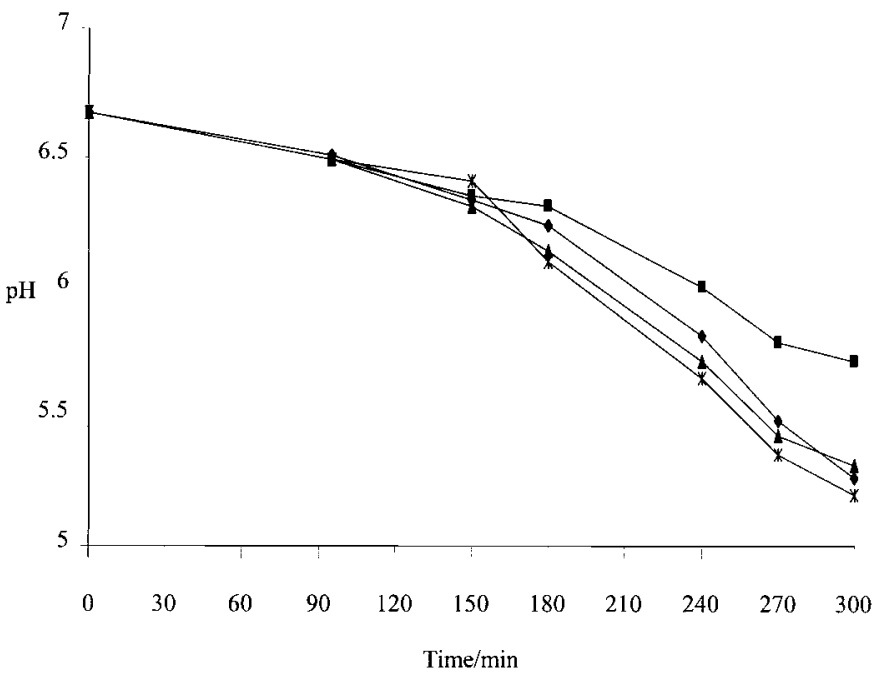

Figure 6. $\mathrm{pH}$ profiles of laboratory-scale Cheddar cheeses manufactured with $1.5 \%$ Lactococcus lactis $\mathrm{HP},(\diamond)$; $1.5 \%$ L. lactis $\mathrm{HP}+$ $0.8 \% 3286(\square) ; 1.5 \%$ L. lactis HP + 0.8\% DPC5552 ( ) and $1.5 \%$ L. lactis $\mathrm{HP}+0.8 \%$ L. lactis $481(\times)$.

significantly lower $(0.40 \mathrm{U} / \mathrm{ml})$ than that observed with DPC5552 (Figure 5).

\section{Lacticin 481-Producing Cultures Cause Elevated Enzyme Release in Laboratory Scale Cheddar Cheese}

Laboratory-scale cheese trials were performed using HP (sacrificial strain), and each of the bacteriocin-producing strains, DPC3286, L. lactis 481 and DPC5552, and the $\mathrm{pH}$ profiles are presented in Figure 6. LDH release in cheese manufactured with $1.5 \% \mathrm{HP}$ alone (Vat 1 ) was $0.278 \pm 0.086 \mathrm{U} / \mathrm{ml}$ cheese juice. In contrast, inclusion of $0.8 \%$ DPC3286 yielded a substantial increase in $\mathrm{LDH}$, with levels of $1.108 \pm 0.395 \mathrm{U} / \mathrm{ml}$ being recorded. Similarly, vats 3 and 4 containing $1.5 \% \mathrm{HP}$ $+0.8 \%$ DPC5552 and $1.5 \%$ HP $+0.8 \%$ L. lactis 481, respectively, demonstrated elevated LDH levels of $2.671 \pm 1.516$ and $3.705 \pm 1.633 \mathrm{U} / \mathrm{ml}$ of cheese juice, respectively. Vat 1 , containing $L$. lactis $\mathrm{HP}$ as the sole starter, reached the milling $\mathrm{pH}$ of $\sim 5.2$ within the required $5 \mathrm{~h}$ of manufacturing time desired by Cheddar manufacturers. In vat 2 , acid production by HP was severely compromised by the inclusion of the adjunct DPC3286, with the $\mathrm{pH}$ after $5 \mathrm{~h}$ being $\sim 5.7$. This type of scenario, where acidification is compromised, is highly undesirable by Cheddar manufacturers as it extends manufacturing time and leads to economic losses. Interestingly, in vats 3 and 4, where lacticin 481-producers act as adjuncts, there was no slowdown in acid production by $\mathrm{HP}$ with the vats reaching a $\mathrm{pH}$ of $\sim 5.25$ in 5 h. It is from these vats that the highest $\mathrm{LDH}$ readings were recorded.

\section{DISCUSSION}

In this study, we have demonstrated that the lantibiotic lacticin 481 has a bacteriolytic effect on sensitive lactococci and causes the release of intracellular enzymes from growing lactococcal cultures over and above those observed in the presence of other bacteriolytic bacteriocins. In a recent study by Walker and Klaenhammer (2001), a system that involved the controlled expression of holin and lysin was described that resulted in a 'leaky phenotype' in lactococci. This report described the introduction of a late promoter from the lytic lactococcal bacteriophage $\phi 31$, fused to lac Z $\left(\mathrm{P}_{15 \mathrm{~A} 10}::\right.$ lac $\left.\mathrm{Z}\right)$ into a number of $L$. lactis strains. The resulting leakage of $\beta$-galactosidase at high levels into the supernatant was attributed to expression of a transcriptional activator from the promoter $\mathrm{P}_{15 \mathrm{~A} 10}$, which activated a homologous late promoter in prophages harbored by the lactococcal strains. Low-level activation of the late promoter, driving downstream expression of holin and lysin, resulted in the leaky behavior. Interestingly, only cloned $\beta$-galactosidase $(540 \mathrm{kDa})$ and tetanus toxin fragment $\mathrm{C}(<100 \mathrm{kDa})$ were leaked successfully from the cells, whereas peptidases such as X-prolyl dipeptidyl aminopeptidase were not detected extracellularly at significant levels. These intracellular components were leaked from the cell without the use of signal sequences and without causing severe losses of cell viability or integrity.

In this study, the elevated enzyme release observed on exposure to lacticin 481 could be caused by a leakiness' of the culture due to transient pore formation. Indeed, a structurally similar lantibiotic streptococcin A-FF22 has been shown to cause short-lived unstable pores in the cytoplasmic membrane (Jack et al., 1994). However, these pores are somewhat smaller than those of some previously described pore-forming lantibiotics and could not allow sufficient efflux of large molecules such as ATP. Indeed, death of SA-FF22-affected cells seems to result from potential membrane disruption and subsequent exhaustion of the cells. In this study, we have observed the release of the relatively large enzymes, LDH (140 kDa) and Pep X (194 kDa), from lacticin 481-treated lactococcal starters. Since it is hard to envisage how such enzyme-releasing cells could remain viable, it seems more likely that such a phenomenon could be explained by the gradual death and lysis/ permeabilization of some cells in the culture, while simultaneously other cells continue to grow and multiply. Recent experiments have demonstrated that AcmA activity does not seem to be required for the lysis/permea- 
bilization of lactococcal (MG1363) cells exposed to high concentrations of lacticin 481 (32 AU/ml) (results not shown). However, why some cells within a culture are susceptible to lysis/permeabilization is not known but could be related to growth-phase and physiology of individual cells. It may also be that the bacteriocin concentration is so low that only a proportion of the sensitive cells have bound sufficient lacticin 481 molecules to cause pore formation, resulting in cell lysis/permeabilization and subsequent release of $\mathrm{LDH}$ and Pep X. When bacteriocin-treated cells are subjected to Baclight viability staining, approximately $45 \%$ of an L. lactis ML8 culture remains viable (nonlysed) following exposure to $512 \mathrm{AU} / \mathrm{ml}$ DPC5552 supernatant. Associated with this is a 17 -fold increase in LDH released over the control of L. lactis ML8 without bacteriocin. Interestingly, when L. lactis ML8 is treated with the same concentration of DPC3286 bacteriocin, no viable cells were detected after $4 \mathrm{~h}$, and there was no associated increase in the quantity of LDH released. Importantly, this situation whereby a growing culture (as assessed by increase in optical density) releases increased enzyme levels could not be achieved by varying the concentrations of lactococcins A, B, and M and lacticin 3147 (Figure 4).

The observations made in this study may offer an important advantage when applied to the exploitation of bacteriocin-induced lysis/permeabilization for starter culture improvement regimes, e.g., Cheddar cheese manufacture. In fact, permeabilization rather than cell lysis would be desirable during cheese making to prevent intracellular enzyme loss in whey. Significantly larger amounts of intracellular enzyme release can be achieved in situations in which lacticin 481-producing cultures are exploited. An additional advantage associated with the use of such cultures would be that the strain targeted to lyse/permeabilize continues to grow and, thus, can contribute to acid production during cheese manufacture. Pilot-scale cheese trials have been performed that demonstrated elevated enzyme release in cheese manufactured with an adjunct producing lacticin 481 (results not shown).

\section{ACKNOWLEDGMENTS}

This work was supported by the FAIR section (Fair CT98-4396) of the European Community Framework Programme IV. Lisa O'Sullivan is funded by a Teagasc Walsh Fellowship. The authors would like to thank Máire Ryan and Paula O'Connor for helpful suggestions and discussions.

\section{REFERENCES}

Abee, T. 1995. Pore-forming bacteriocins of gram-positive bacteria and self-protection mechanisms of producer organisms. FEMS Microbiol. Lett. 129:1-10.
Ardö, Y., and H. E. Petterson. 1988. Accelerated cheese ripening with heat-treated cells of Lactobacillus helveticus and a commercial proteolytic enzyme. J. Dairy Res. 55:239-245.

Asensio, C., L. Parra, C. Peláez, and R. Gómez. 1995. Use of heatshocked mesophilic lactic acid bacteria in low-fat goats' milk cheesemaking. J. Agric. Food Chem. 44:2919-2923.

Aston, J. W., and J. R. Dulley. 1982. Cheddar cheese flavor. Aust. J. Dairy Technol. 37:59-64.

Aston, J. W., and L. K. Creamer. 1986. Contribution of the components of the water-soluble fraction to the flavor of Cheddar cheese. N.Z. J. Dairy Sci. Technol. 21:229-248.

Auty, M. A., M. Twomey, T. P. Guinee, and D. M. Mulvihill. 2001. Development and application of confocal scanning laser microscopy methods for studying the distribution of fat and protein in selected dairy products. J. Dairy Res. 68:417-427.

Bie, R., and G. Sjostrom. 1975a. Autolytic properties of some lactic acid bacteria used in cheese production. Part I: Materials and Methods. Milchwissenschaft 30:653-657.

Bie, R., and G. Sjostrom. 1975b. Autolytic properties of some lactic acid bacteria used in cheese production. Part II: Experiments with fluid substrates and cheese. Milchwissenschaft 30:739-747.

Booth, M., I. Ní Fhaoláin, P. V. Jennings, and G. O'Cuinn. 1990. Purification and characterization of a post-proline dipeptidyl aminopeptidase from Streptococcus cremoris AM2. J. Dairy Res. 57:89-99.

Bruno, M. E. C., and T. J. Montville. 1993. Common mechanistic action of bacteriocins from lactic acid bacteria. Appl. Environ. Microbiol. 59:3003-3010.

Casal, V., L. G. Parra, C. Peláez, and R. Gómez. 1996. Sensitivity of lactic acid bacteria to high hydrostatic pressure treatment. Fifth Symposium on Lactic Acid Bacteria. Genetics, Metabolism, and Applications, Veldhoven, The Netherlands, September 1996, G26.

Chapot-Chartier, M. P., C. Deniel, M. Rousseau, L. Vassal, and J. C. Gripon. 1994. Autolysis of two strains of Lactococcus lactis during cheese ripening. Int. Dairy J. 4:251-269.

Cliffe, A. J., J. D. Marks, and F. Mulholland. 1993. Isolation and characterization of nonvolatile flavors from Cheddar: Peptide profile of flavor fractions from Cheddar cheese, determined by reverse-phase, high-performance liquid chromatography. Int. Dairy J. 3:379-387.

Crow, V. L., T. Coolbear, P. K. Gopal, F. G. Martley, L. L. McKay, and H. Riepe. 1995a. The role of autolysis of lactic acid bacteria in the ripening of cheese. Int. Dairy J. 5:855-875.

Crow, V. L., F. G. Martley, T. Coolbear, and S. J. Roundhill. 1995b. The influence of phage-assisted lysis of Lactococcus lactis subsp. lactis ML8 on Cheddar cheese ripening. Int. Dairy J. 5:451-472.

Cunniffe, A. 1998. Isolation and characterization of two bacteriocinogenic Lactococcal strains. MSc. Thesis. Natl. Univ. Ireland, Cork, Ireland.

Engels, W. J. M., and S. Visser. 1994. Isolation and comparative characterization of components that contribute to the flavor of different types of cheese. Neth. Milk Dairy J. 48:127-140.

Feirtag, J. F., and L. L. McKay. 1987a. Thermoinducible lysis of temperature-sensitive Streptococcus cremoris strains. J. Dairy Sci. 70:1779-1784.

Feirtag, J. F., and L. L. McKay. 1987b. Isolation of Streptococcus lactis C2 mutants selected for temperature sensitivity and potential use in cheese manufacture. J. Dairy Sci. 70:1773-1778.

Gasson, M. J. 1983. Plasmid complements of Streptococcus lactis NCDO 712 and other lactic streptococci after protoplast-induced curing. J. Bacteriol. 154:1-9.

Heap, H. A., and R. C. Lawrence. 1981. Recent modifications to the New Zealand activity test for Cheddar cheese starters. N.Z. J. Dairy Sci. Technol. 16:91-94.

Hoffman, C. S., and F. Winston. 1987. A 10-min DNA preparation from yeast efficiently releases autonomous plasmids for transformation of Escherichia coli. Gene 57:267-272.

Jack, R., R. Benz, J. Tagg, and H. G. Sahl. 1994. The mode of action of SA-FF22, a lantibiotic isolated from Streptococcus pyogenes strain FF22. Eur. J. Biochem. 15:219(1-2):699-705. 
Kamaly, K. M., M. E. Johnson, and E. H. Marth. 1989. Characteristics of Cheddar cheese made with mutant strains of lactic streptococci as adjunct sources of enzymes. Milchwissenschaft. 44:343-346.

Kok, J., H. Holo, M. J. van Belkum, A. J. Haandrikman, and I. F. Nes. 1993. Non-nisin bacteriocins in lactococci: Biochemistry, genetics, and mode of action. Pages 121-150 in Bacteriocins of Lactic Acid Bacteria. D. Hoover and L. Steenson (ed.). Acad. Press, New York.

Law, B. A., M. J. Castañon, and M. E. Sharpe. 1976. The contribution of starter streptococci to flavor development in Cheddar cheese. J. Dairy Res. 43:301-311.

Martínez-Cuesta, M. C., C. Peláez, M. Juárez, and T. Requena. 1997. Autolysis of Lactococcus lactis ssp. lactis and Lactobacillus casei ssp. casei. Cell lysis induced by a crude bacteriocin. Int. J. Food Microbiol. 38:125-131.

Martínez-Cuesta, M. C., P. Fernández de Palencia, T. Requena, and C. Peláez. 1998. Enhancement of proteolysis by a Lactococcus lactis bacteriocin producer in a cheese model system. J. Agric. Food Chem. 46:3863-3867.

Martínez-Cuesta, M. C., G. Buist, J. Kok, H. H. Hauge, J. NissenMeyer, C. Peláez, and T. Requena. 2000a. Biological and molecular characterization of a two-peptide lantibiotic produced by Lactococcus lactis IFPL105. J. Appl. Micro. 89:249-260.

Martínez-Cuesta, M. C., J. Kok, E. Herranz, C. Peláez, T. Requena, and G. Buist. 2000b. Requirement of autolytic activity for bacteriocin-induced lysis. Appl. Environ. Microbiol. 66:3174-3179.

Mills, S., A. Coffey, L. O'Sullivan, D. Stokes, C. Hill, G. F. Fitzgerald, and R. P. Ross. 2001. Use of lacticin 481 to facilitate delivery of the bacteriophage resistance plasmid, pCBG104 to cheese starters. J. Appl. Microbiol. 91:1-9.

Moll, G., H. Hildeng-Hauge, J. Nissen-Meyer, I. F. Nes, W. N. Konings, and A. J. M. Driessen. 1988. Mechanistic properties of the two-component bacteriocin lactococcin G. J. Bacteriol. 180:96-99.

Morgan, S. M., R. P. Ross, and C. Hill. 1995. Bacteriolytic activity caused by the presence of a novel lactococcal plasmid encoding lactococcin A, B, and M. Appl. Environ. Microbiol. 61:2995-3001.

Morgan, S., R. P. Ross, and C. Hill. 1997. Increasing starter cell lysis in Cheddar cheese using a bacteriocin-producing adjunct. J. Dairy Sci. 80:1-10.
O'Sullivan, D., R. P. Ross, G. F. Fitzgerald, and A. Coffey. 2000. Investigation of the relationship between lysogeny and lysis of Lactococcus lactis in cheese using prophage-targeted PCR. Appl. Environ. Microbiol. 66:2192-2198.

Parente, E., and C. Hill. 1992. A comparison of factors affecting the production of two bacteriocins from lactic acid bacteria. J. Appl. Bacteriol. 73:290-298.

Piard, J. C., P. M. Muriana, M. J. Desmazeaud, and T. R. Klaenhammer. 1992. Purification and partial characterization of Lacticin 481, a lanthionine-containing bacteriocin produced by Lactococcus lactis subsp. lactis CNRZ 481. Appl. Environ. Microbiol. 58:279-284.

Piard, J. C., O. P. Kuipers, H. S. Rollema, M. J. Desmazeaud, and W. M. de Vos. 1993. Structure, organization, and expression of the lct gene for Lacticin 481, a novel lantibiotic produced by Lactococcus lactis. J. Biol. Chem. 268:16361-16368.

Rince, A., A. Dufour, S. LePogam, D. Thuault, C. M. Bourgeois, and J. P. LePennec. 1994. Cloning, expression, and nucleotide sequence of genes involved in production of lactococcin DR, a bacteriocin from Lactococcus lactis subsp. lactis. Appl. Environ. Microbiol. 60:1652-1657.

Shearman, C. A., K. Jurry, and M. J. Gasson. 1992. Autolytic Lactococcus lactis expressing a lactococcal bacteriophage lysin gene. Bio/Technology 10:196-199.

Terzaghi, B. E., and W. E. Sandine. 1975. Improved medium for lactic streptococci and their bacteriophages. Appl. Environ. Microbiol. 29:807-813.

Walker, S. A., and T. R. Klaenhammer. 2001. Leaky Lactococcus cultures that externalize enzymes and antigens independently of culture lysis and secretion and export pathways. Appl. Environ. Microbiol. 67:251-259.

Wilkinson, M. G., T. P. Guinee, D. M. O'Callaghan, and P. F. Fox. 1994. Autolysis and proteolysis in different strains of starter bacteria during Cheddar cheese ripening. J. Dairy Res. 61:249-262.

Wittenberger, C. L., and N. Angelo. 1970. Purification and properties of a fructose 1,6-diphosphate-activated lactate dehydrogenes from Streptococcus faecalis. J. Bacteriol. 101:717-734.

Yokoyama, H., N. Sawamura, and N. Motobayshi. 1994. Method for accelerating cheese ripening. European Patent Specification 0469 857 B1. 